\title{
The Prevalence and Severity of Sickle Cell Disease in Amravati District of Maharashtra
}

\author{
Maryam. M. Ahmad*, H. N Gupta, D.S. Shinde, N. D Ruparel \\ Department of Pharmacy Practice, Government College of Pharmacy, Amravati, Maharashtra, 444604, INDIA.
}

\begin{abstract}
Objective: The present study was undertaken to determine the prevalence and severity of Sickle Cell Disease among carriers and sufferers belonging to Amravati district. Methodology: Screening camps were held in different regions from which only positive groups of sickle cell solubility were considered for prevalence. A patient interview form was prepared with informed consent. The questionnaire was prepared with a view to collect data on the disease status of the sufferers only. Results: It was found that overall prevalence of sickle cell disease was $1 \%$ in the population mostly in SC, ST and Adivasi community (which represent economically backward population); more common in male gender. Age wise distribution of incidence of carriers was higher in adult age group while more sufferers were of the lower age group. Data regarding the prophylactic treatment impact revealed that patients receiving treatment had a successfully improved symptoms and an increase in the hemoglobin levels.
\end{abstract}

Key words: Sickle cell disease, Haemoglobinopathies, Prevalence, Severity.

\section{INTRODUCTION}

Hemoglobin is critical for normal oxygen delivery to tissues. It is present in erythrocytes in such high concentrations that it can alter red cell shape and deformability. Haemoglobinopathies are characterized by defects in the structure, function, or production of hemoglobin. These conditions are usually inherited and range in severity from asymptomatic laboratory abnormalities to death in utero. Structural hemoglobinopathies occur when mutations alter the amino acid sequence of a globin chain, altering the physiologic properties of the variant hemoglobins and producing the characteristic clinical abnormalities. The sickle cell syndromes are caused by a mutation in the $\alpha$-globin gene that changes the sixth amino acid from glutamic acid to valine producing characteristic sickle shape. ${ }^{1}$ Sickled cells lose the flexibility needed to traverse small capillaries. They possess altered sticky membranes (especially reticulocytes) that are abnormally adherent to the endothelium of small venules. These abnormalities provoke unpredictable episodes of microvascular vaso-occlusion causing tissue ischemia, acute pain, gradual end-organ damage and premature RBC destruction (hemolytic anemia). ${ }^{2,3}$ Prominent manifestations include episodes of ischemic pain (i.e., painful crises) and ischemic malfunction or frank infarction in the spleen, central nervous system, bones, liver, kidneys, and lungs. Of the many methods available for hemoglobin analysis, electrophoretic techniques are used for routine clinical purposes. Comparison of results obtained in each system usually allows unambiguous diagnosis, but some important variants are electrophoretically silent. The mutant hemoglobin can usually be characterized by more specialized techniques such as isoelectric focusing and/or High Pressure Liquid Chromatography (HPLC). The best sickling assays involve measurement of the degree to which the hemoglobin sample becomes insoluble, or gelated, as it is deoxygenated (i.e., sickle solubility test). Diagnosis is confirmed by hemoglobin electrophoresis and the sickling test. ${ }^{4}$ The purpose of this study is to evaluate the present status of carriers and sufferers and to determine its prevalence and severity among carriers and sufferers belonging to Amravati district of Maharashtra. As the socio-
DOI: 10.5530/ijopp.11.4.42

Address for correspondence: Maryam. M. Ahmad Department of Pharmacy Practice, Government College of Pharmacy, Amravati, Maharashtra, 444604, INDIA.

Email Id: maryam418@rediffmail.com

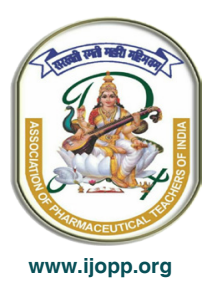


economic factor plays a major role in the progression of the disease, there is a need to make people aware of the disease in areas where there is poverty and lack of education in the interiors and backward tribal areas as to achieve better outcomes in future.

\section{MATERIALS AND METHODS}

This prospective study was carried out in Amravati District of Vidarbha in the state of Maharashtra, for the period of one year. A total of 250,424 subjects were screened in complete one year period. Patient interview form was prepared by considering all etiological factors with informed consent. The questionnaire of sickle cell was prepared with a view to collect data on the disease status of the sufferers only. The collected data was organized using MS-excel. The carrier and the sufferer data were separately represented. The diseased data was further analyzed and represented graphically.

\section{Primary screening}

Systematic mass screening camps were carried out in various schools and at the community level during which a number of individuals comprising males and females from Amravati district of Vidarbha region were screened for hemoglobin-S using solutions of qualitative solubility test and High Performance Liquid Chromatography (HPLC)/electrophoresis respectively. Data was collected from the different areas of Amravati District. For the primary screening test, 20 micro liters $(\mathrm{mcg})$ blood sample was collected from finger prick and mixed thoroughly with solutions supplied with solubility kits. Result for hemoglobin-S variant was noted after 3 minutes. The sample with turbidity and opacity was considered positive for sickle cell. Positive cases were subjected to further conformation at District General Hospital (DGH), Amravati.

\section{Confirmatory test}

$2 \mathrm{ml}$ intravenous blood sample was withdrawn for further analysis and patients were interviewed. Hematological indices were measured using calibrated electronic recording machine accounting (ERMA) particle counter. Laboratory investigations were carried out by HPLC and electrophoresis following a standard procedure as described by Dacie and Lewis. ${ }^{5}$ All the samples were subjected to hemoglobin electrophoresis using cellulose acetate membrane in alkaline TBE (Tris/Borate/EDTA) buffer at $\mathrm{pH} 8.9$ for pattern confirmation. The known samples (control) of $\mathrm{HbS}$ along with present samples were run for electrophoresis. ${ }^{6}$

\section{RESULTS AND DISCUSSION}

Following tables represent data of one year period April 2015 to March 2016 under the sickle cell control program. The data was collected from Day Care Center of District General Hospital, Amravati.

\section{Physical Performance}

Out of the 250424 samples screened, 3802 were run on Electrophoresis, out of which 2511 were positive and 1291 were negative. Out of 2511 positive samples, 2313 were found to be of carriers and 198 samples were found to be of sufferers. Thus, the overall prevalence of Sickle cell carriers was $0.9 \%$.

\section{Community-wise distribution}

Amongst SC and ST category populations (which are considered to be economically backward), high prevalence for carriers was observed $(1.832 \%$, and $1.33 \%$ respectively) as compared to rest of the population $(0.004 \%)$. Whereas, prevalence for sufferers was also high in SC and ST category $(0.0015 \%$ and $0.0013 \%$ respectively) as compared to rest of the population $(0.00029 \%)$. This is similar to the study conducted by Chatruvedi and Kamble in which incidence was maximum in the Mahar community $(70 \%)$ followed by Kunbi (8\%) and Teli (6\%).

\section{Tehsil-wise distribution}

The prevalence of Sickle cell Carriers and sufferers analyzed according to the Tehsil places of the Amravati District. Chikhaldara, Dharni and Warud had the highest prevalence of the carriers while Achalpur, Bhatkuli and Nandgaon Khandeshwar had the highest prevalence of the sufferers (Figure 1a and 1b). This fact indicates that carriers are more in the Adivasi (common in Korku tribe) community, which is more in Chikhaldara Tehsil and is more prone to develop SCD. The suspected reason behind this may be high prevalence of incidences of consanguineous marriage, illiteracy and lack of knowledge about the disease. Premarital screening and genetic counseling needs to be considered as important tools to control its gene frequency. This study is similar to the previous study conducted by Deore AU, Zade SB. ${ }^{8}$

\section{Gender-wise distribution}

It was found that though less male population screened, the prevalence for both carrier and sufferer was higher in males $(1.812 \%$ and $0.176 \%$ respectively) as compared to females $(0.802 \%$ and $0.106 \%$ respectively). (Table 1$)$

This finding is in compliance with study conducted earlier 


\begin{tabular}{cccc}
$\begin{array}{c}\text { Table 1: Gender wise distribution of carriers and } \\
\text { sufferers }\end{array}$ & \multicolumn{3}{l}{} \\
\hline Gender & $\begin{array}{c}\text { Total population } \\
\text { tested }\end{array}$ & Carriers & Sufferers \\
\hline Male & 50000 & $906(1.812 \%)$ & $88(0.176 \%)$ \\
Female & 175424 & $1407(0.802 \%)$ & $187(0.106 \%)$ \\
\hline
\end{tabular}

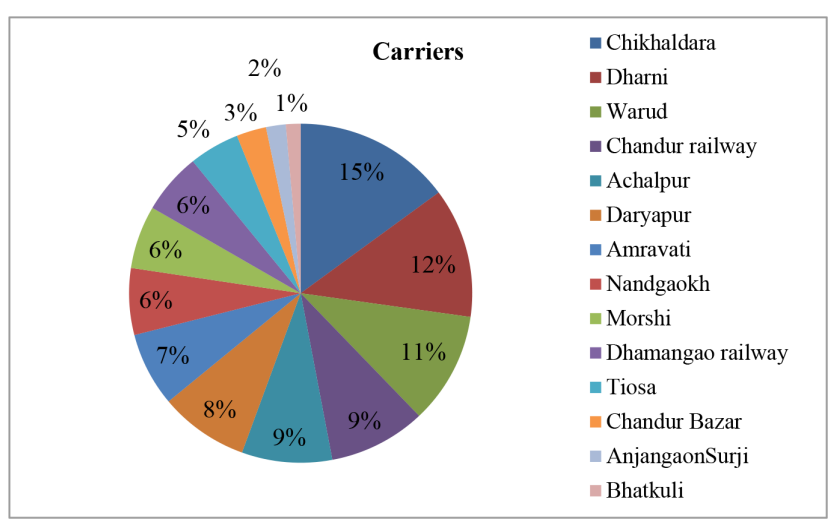

Figure 1a. Tehsil wise distribution of carriers

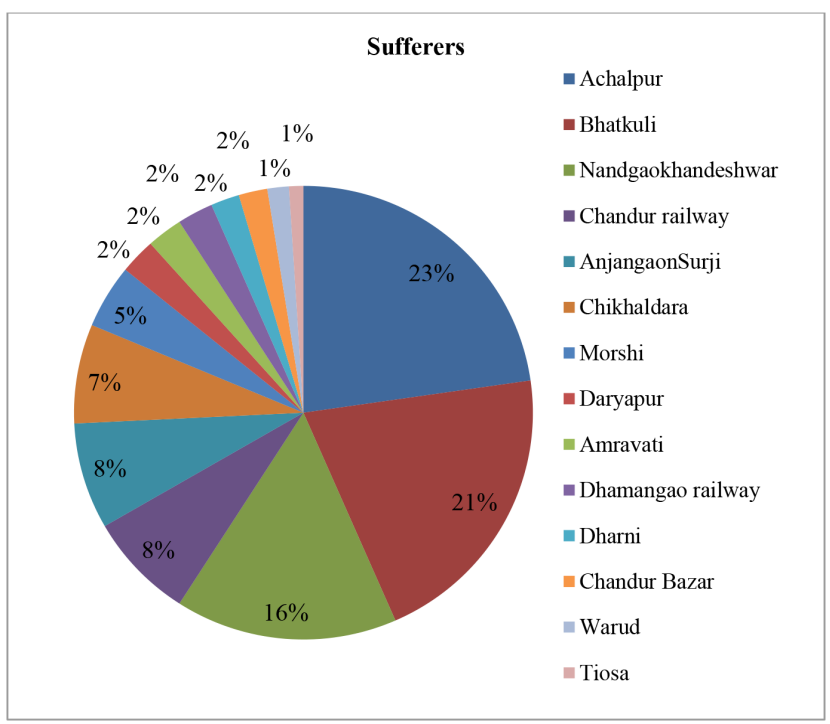

Figure 1b. Tehsil wise distribution of sufferers

by Sukhsohale et al. (2013), where prevalence of SCD was analyzed amongst students.

\section{Age-wise distribution}

Figure $2 \mathrm{a}$ and $2 \mathrm{~b}$ represents the age wise distribution of population under study. Testing is generally done for the age up to 25 years as per the Hospital policy. It was found that in the age group above 20 (and up to 25) there was more incidence of the carriers. As the carriers remain asymptomatic, and live healthy life, most of the cases are unaware of the trait. But such carriers are more prone to pass on the disease to next generation and may give birth to sufferers. Therefore, the incidence of carrier may be

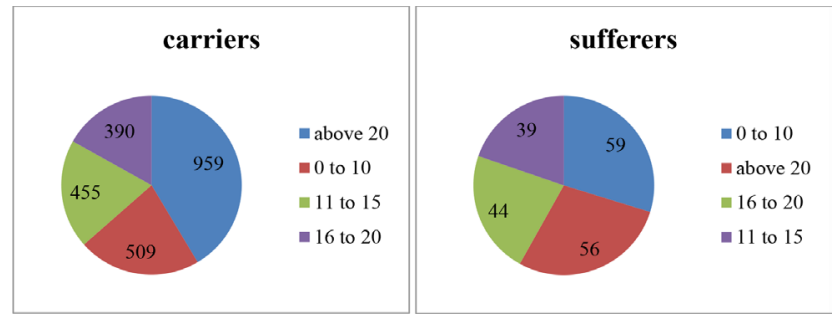

Figure 2a. Age wise distribution of carriers Figure 2b. Age wise distribution of sufferers

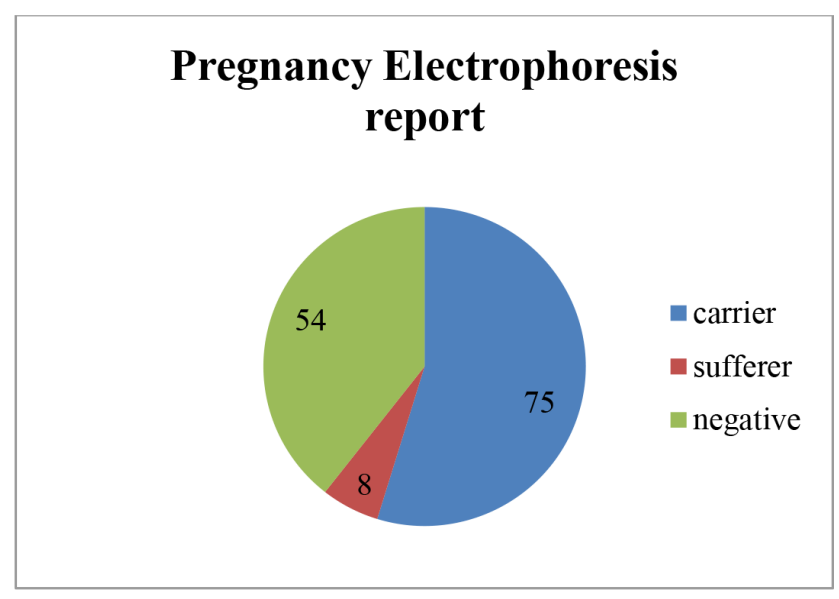

Figure 3: Pregnancy electrophoresis report of sickle cell

higher in adult age group, but sufferers are found more in lower age group.

\section{Impact of the prophylactic treatment}

The treatment review revealed that out of 198 patients, all received regular prophylactic treatment which included Folic acid and Vitamin C supplement. Out of these, $54 \%$ school going children could be able to attend school regularly because of treatment. In $29 \%$ patients, hemoglobin gram per cent $(\mathrm{Hb} \mathrm{gm} \%)$ was increased significantly without need of blood transfusion and Hydroxyurea, whereas, 17\% patients did not show any response to the treatment. This finding supports positive impact of prophylactic treatment on quality of life of sufferers. However, data regarding total number of school going children is lacking.

\section{Pregnancy solubility and Electrophoresis report of sickle cell}

Considering the fact that a carrier pregnant woman may give birth to a carrier or sufferer offspring, we have collected data of solubility testing of pregnant patients. It was found that out of 14,166 pregnant mothers tested for solubility, 137 were positive. Positive samples were sent for electrophoresis. On electrophoresis test of the 137 solubility positive samples, 75 samples were confirmed as Indian Journal of Pharmacy Practice, Vol 11, Issue 4, Oct-Dec, 2018 
carriers, 8 were sufferers and 54 were negative (Figure 3).

This implicates that all electrophoresis negative samples (54) were showing false positive result in solubility test. Therefore solubility test is meant only for screening and not for confirmed diagnosis of the SCD.

\section{CONCLUSION}

In this prospective study, it was found that overall prevalence of sickle cell disease was 1\%. The prevalence of Sickle cell sufferers was found in lower age group males of SC and ST category (Adivasi Community, commonly Korku tribe) belonging to Chikhaldara Tehsil whereas, prevalence of carriers was found to be in higher age group males. Impact analysis of prophylactic treatment reveals recovery in sufferers. However, the recovery is yet to be improved in order to get satisfactory treatment outcome.

\section{ABBREVIATIONS}

SC: Schedule Caste; ST: Schedule Tribe; SCD: Sickle Cell Disease.

\section{REFERENCES}

1. Lervolino LG, b.P., Picado SMI, Calil KB, Viel AAI, Campos LAF. Prevalence of sickle cell disease and sickle cell trait in national neonatal screening studies. Reviologia e Hemoterapiamasta Brasileira de Hemoterapia. 2009;33(1):49-54.

2. Leikin SL, Gallagher D, Kinney TR, Sloane D, Klug P, Rida W. Mortality in children and adolascents with sickle cell disease. Pediatrics. 1989;84(3):500-8.

3. Prasad R, Hasan S, Castro, Perlin E, Kim K. Longterm outcomes in patients with sickle cell disease and frequent vaso-occlusive crises. American Journal of the Medical Sciences. 2003;325(3):107-9.

4. Longo DL, F.A., Kasper DL, Hauser SL, Jameson J, Loscalzo J, Harison's, principle of internal medicine. New york: McGraw-Hill 2012.

5. Dacie JV, Lewis SM, White JM, Marsh GW. Investigation of Abnormal Haemoglobins and Thalassaemia. In: Dacie JV, Lewis SM, editors. Practical Haematology. London: Churchill Livingstone. 1991;227-57.

6. Urade B.P. Incidence of Sickle Cell Anaemia and Thalassaemia in Central India. Open Journal of Blood Diseases. 2012;2(4):71.

7. Chatruvedi $P$, Kamble M. Epidemiology of sickle cell disease in a rural hospital of central india. Indian Pediatrics. 2000;37(4):391-6.

8. Deore AU, Zade SB. Distribution of Sickle Cell Gene in Korku Tribe of Central India. Natl J Community Med. 2014;5(3):270-2. 